\title{
INTERGENERATIONAL JUSTICE TODAY
}

\author{
Andre Santos Campos
}

\author{
Correspondence \\ Andre Santos Campos \\ Nova University of Lisbon \\ Faculty of Social Sciences and Humanities \\ Av. de Berna, 26 - 4th floor, 1069 - 061 Lisbon. \\ Email: andrecampos@fcsh.unl.pt
}

\begin{abstract}
A theory of intergenerational justice consists in the study of the moral and political status of the relations between present and past or future people, more specifically, of the obligations and entitlements they can potentially generate. The challenges that justify talking about responsibilities between generations are myriad (e.g., the amount of public debt that is fair to incur; the funding of future pensions; reparations for past wrongs; climate change). And the disputes they prompt can focus on the past just as much as on the present, even though the fact that the human species has reached a state of technological progress that enables it to have an irredeemable impact on the planet and perhaps even endanger future human existence tends to make concerns about the future more pressing. Debates on intergenerational justice are twofold. The first revolves around the issue of whether claims of justice across generations whose members' lifetimes do not necessarily overlap could be justified. And the second revolves around the specific conception of justice in play, that is, around the nature of the standard that must be applied as well as around the identification of the contents of the duties that present generations supposedly have vis - à - vis past or future generations. This survey article depicts the conceptual and argumentative framework in which these debates are set. It aims to outline certain of the main features shared by the most influential contemporary theories of intergenerational justice, and the problems inherent in them. It concludes by suggesting that, even though the idea of succeeding generations is merely an abstraction, there are specific empirical states of affairs that require different theoretical responses to intergenerational justice.
\end{abstract}

\section{Introduction}

A theory of intergenerational justice consists in the study of the moral and political status of the relations between present and past or future people, more specifically, of the obligations and entitlements they can potentially generate. Within such a frame of reference, past or future generations might have legitimate claims or rights against present generations, who in turn might have correlative responsibilities or duties towards past or future generations. 
The challenges that justify talking about responsibilities between generations are myriad. They comprise the amount of public debt that is fair to incur; the enactment of long-standing legal rules in constitutional frameworks; the proper funding for future pensions; reparations for past wrongs; the social response to high unemployment rates among young people; the combat against climate change; etc. And the disputes they prompt can focus on the past just as much as on the present. However, the fact that the human species has reached a state of technological progress that enables it to have an irredeemable impact on the planet (thus inaugurating a new geological era called the Anthropocene) and perhaps even endanger future human existence tends to make concerns about the future more pressing.

This survey article depicts the conceptual and argumentative framework in which debates on intergenerational justice are set. It aims to outline some of the main features shared by the most influential contemporary theories of intergenerational justice, and the problems inherent in them. It concludes by suggesting that, even though the idea of succeeding generations is merely an abstraction, there are specific empirical states of affairs that require different theoretical responses to intergenerational justice.

\section{Is There a Basis for Intergenerational Justice?}

A first debate on intergenerational justice revolves around the issue of whether claims of justice across generations whose members' lifetimes do not necessarily overlap ${ }^{1}$ could be justified. It expresses a frame of reference with three basic characteristics.

(i) Moral status of non-overlapping generations. The underlying conception of time encompasses the past (determinism), the present (actuality) and the future (non-determinism). Intergenerational justice applies to transgenerational communities, that is, communities whose different generations do not necessarily coexist in a particular moment; but it is addressed specifically to

\footnotetext{
${ }^{1}$ Non-simultaneity is not a necessary condition of intergenerational justice. However, the relations between non-simultaneous moral agents are different from the relations between simultaneous moral agents. Depending on the definition of 'generation', justice is conceivable either between the present and past or future generations (intertemporal generations) or between the young and the old (temporal generations) (Tremmel 2009, 4). Justice between temporal generations can be tackled by general theories of justice, which are theories of intragenerational justice; but justice between intertemporal generations extends beyond the scope of general theories of justice, thus bringing about theories of intergenerational justice.
} 
members of present generations, who are required to take into consideration the moral status of members of past and future generations.

(ii) Non-reciprocity between non-overlapping generations. There is neither mutual cooperation nor any kind of exchanges between individuals belonging to non-simultaneous generations.

\section{(iii) Asymmetry in power-relations between non-overlapping generations.}

Requirements of intergenerational justice involve the intention of balancing what seems to be an unsurpassable power of present generations vis-à-vis past or future generations. However, the means of diminishing this asymmetry are fundamentally different, given that present generations may be said to exercise power over future generations but not over past ones. Whereas intergenerational justice applied to the relations between present and future generations usually concerns a proper distribution of goods and a respect for the (possible) rights of future people, intergenerational justice applied to the relations between present and past generations usually concerns reparations for past wrongs towards the descendants of victims. ${ }^{2}$

Scepticism about theories of justice focused exclusively on intergenerational relations rejects that the aforementioned characteristics cannot be met by standard theories of justice ${ }^{3}$, especially with regard to arguments about the future (rather than the past) to support special kinds of moral responsibilities upon present generations. In the present-future relation, scepticism consists in a refusal to commit to the idea that there is such a thing as obligations in the present to future people in the sense that such

\footnotetext{
${ }^{2}$ The problem of moral reparation for past actions is expressed chiefly in debates about the rights of present people to receive compensation for wrongs committed against their ancestors, especially with regard to the victims of slavery and of the Holocaust. But the past may also be important when identifying a just distribution of goods in the present, such as when $\mathrm{CO} 2$ emissions of the past determine the effective reduction rates to be enforced in the present (Gosseries 2004).

${ }^{3}$ Scepticism can be traced back to Thomas Jefferson's dictum that 'the earth belongs in usufruct to the living' (Jefferson 2004, 599). Jefferson's theses were expounded in correspondence with James Madison and John Wayles Eppes about constitutional revisions and the limits of public debt, and they were shared by Thomas Paine and other authors sympathetic to the ideals of the French Revolution (for instance, article 6 of the Universal Declaration of the Rights of Man and Citizen adopted by the French constitution of 1793 stated that 'One generation cannot submit the future generations to its laws'). The main counterarguments have their origin in Edmund Burke, for whom society is a 'partnership not only between those who are living, but between those who are living, those who are dead, and those who are to be born' (Burke 1962, 140).
} 
obligations can be explained in terms of the specific interests or even correlative rights that future persons may have against persons in the present.

The main source of scepticism is the 'non-identity problem' developed by Thomas Schwartz (1978), Robert Merrihew Adams (1979), Gregory Kavka (1981), and, most forcefully, Derek Parfit (1987). The problem depends upon the claim that the decisions that currently living people make count as necessary conditions not merely of the conditions in which certain people will live in the future but also of their very existence. Derek Parfit's reasoning is as follows: which particular future persons will exist is dependent on when their procreation takes place; even if we could suppose that following certain actions or policies would make future persons worse off, the fact remains that the people born as a result of these actions or policies would not have been born at all if an alternative action or policy had been adopted; therefore, assuming they have lives worth living, they are not harmed by those actions or policies (Parfit 1987, 351-379).

The contingency of future people upon decisions made by present people raises doubts about the possibility of the former having rights (or just claims) that can be violated by the latter. Since present persons' allegedly harmful actions or policies will also influence the identity of future persons, there is a sense in which future persons could not meaningfully be said to be harmed, and even less wronged. And, if persons cannot be harmed, what would rights protect them against?

Two further arguments support this sceptical position. The first is the 'nonexistence' argument (De George 1981; Macklin 1981; Beckerman 2006), which sustains that future persons cannot have rights and reasonable claims in the present since they do not exist. The second is the 'no-satisfaction' argument (De George 1981; Beckerman and Pasek 2001), according to which future persons cannot have a right to resources that do not exist at the time of their existence because such a right could not, in principle, be satisfied.

Reactions to these arguments are myriad. The first is denial, consisting of two different strategies: the 'concessional view' (Elliot 1989; Schlossberger 2008) ${ }^{4}$, which states that rights can exist presently without a holder because they correlate with present

\footnotetext{
${ }^{4}$ Also called 'the meinongian view' (Routley and Routley 1977). Its conceptual frame of reference derives from Feinberg (1974).
} 
duties, and its present existence is contingent on the future existence of some person who will then be the holder of the right; ${ }^{5}$ and the 'constitutive view', which states that a certain course of action might involve the creation of rights that would probably be violated in the future, that is, a present action that may be a cause for a legitimate complaint is constitutive of a future right (Sterba 1980; Woodward 1986; Smolkin 1999).

The second reaction is acceptance, according to which it is not possible to genuinely harm persons who depend on present choices for their very existence nor is it possible to violate rights that never actually exist (Heyd 1992). There are two kinds of moral replies that embrace such sceptic arguments. The first states that they do not have to pose a moral problem since even what seems like the most implausible conclusion regarding possible future persons (for instance, that it is not morally wrong to conceive a blind child even if the same agents could have conceived a sighted child) can be more consonant with common-sense morality than one might think (Boonin 2014). The second kind of reply takes the future out of the equation in order to preserve rights-talk. Such transitive theories conceive of intergenerational justice in terms of rights of living people, whether they are adults with present interests in future states of affairs (Mazor 2010), our children or other children born in our lifetime (Gheaus 2016), any presently existing person (Delattre 1972), or any member of temporally neighbouring generations that will at least at some point in the future have a chance of overlapping (Gosseries 2008).

A third kind of reaction is to attack the sceptic arguments' underlying metaphysics of time and modality. Rather than thinking of duration as a three-point linear order of past, present and future, these reactions talk about identity in terms of an eternalist metaphysics of time in which all moments are actual (Griffith 2017) or about the need for acknowledging alternative accounts of modality encompassing counterpart theory in which possible worlds are equally actual in their own way (Wrigley 2012). The advantage of such reactions is that they prevent a future person from measuring violation of her rights against nonexistence - her rights exist in her world and can be compared with other existing rights in other temporal or possible worlds.

\footnotetext{
${ }^{5}$ A milder version of the concessional view claims that present moral agents have a capacity of foresight (Vanderheiden 2006) or of developing prospective scenarios (Schuessler 2016) in which future rights are to be violated or cannot be waived.
} 
A fourth kind of reaction is to attack the language of rights of future persons, either by derogating or by disconnecting them from personal identity. Derogation follows from a conception of rights inherent in personal identity. If those particular future persons that supposedly will be harmed by present actions will never come to exist, their artificial rights can never justify or be correlatives with present duties. The language of rights seems therefore unfit for the context of moral relations between nonoverlapping generations; instead, it should be replaced by principles establishing that something is wrong either in view of impersonal effects (Parfit 1987 ${ }^{6}$; Brock 1995; Buchanan et al. 2000) or because it contradicts the agents' reasons, attitudes or intentions (Wasserman 2005).

Still, rights terminology can be preserved by reducing personal identity to a contingent aspect of a right. Rights are then attributed to types, of which particular future persons will be mere tokens (Fieser 1992; Herstein 2009; Unruh 2016). There are different levels of abstraction involved in this strategy. A first level interprets the subjects of certain rights to be social roles (Baier 1981) or status-functions (Pletcher 1981) rather than actual persons: for instance, a teacher may be said to have certain duties to future students, even though the latter are indeterminate in their particular identities; it is in the light of their role or status-function that they can be attributed rights without contradiction. A second level of abstraction prefers to think of the subjects of rights in terms of human collectives. Mostly, such collectives are generations - regardless of who the actual future persons will be, intergenerational rights are group rights, that is, generational rights in which the interests protected do not depend upon knowing the individuals (or the numbers) that may exist in any given future generation (Weiss 1990; Kramer 2001; Brännmark 2016; Schuessler 2016). A third level of abstraction attributes rights to future persons because they will share those properties of being human that require present persons to relate morally to them as fellow humans. Such rights are 'generic rights', in accordance with Alan Gewirth's principle of generic consistency (Gewirth 1978). Their generic nature makes duties independent of the existence of particular future persons (Beyleveld et al. 2015).

\footnotetext{
${ }^{6}$ On a posthumously published work, however, Parfit came to accept that the non-identity problem could be overcome by what he called a 'wide person-affecting principle', according to which one of two outcomes is worse if it benefits people less than the other outcome would have (Parfit 2017).
} 
A fifth kind of reaction rejects the person-affecting morality inherent in the nonidentity problem. This involves either separating wronging from harming (Kumar 2003) or opposing Parfit's worse-off argument. Negative responses to the worse-off argument are twofold. It can be rejected on the basis that harming someone does not depend upon a comparative analysis but can be determined absolutely, for instance by assessing whether someone was caused to be simply in a 'bad state' (Benatar 2006; Harman 2009, 137). Or it can be reinterpreted in the sense of a non-counterfactual account that ascribes harm not by comparing a person's current condition with that in which she would otherwise have been if not for the allegedly harmful action, but rather with how she ought to be regardless of the harm done (Hanser 1990; Shiffrin 1999; McMahan 2001; Rivera-Lopez 2009).

All these arguments and counterarguments frame an ongoing debate. It is a mistake to lessen it to a mere theoretical discussion without practical significance since it involves a clarification of the nature of the normative instruments that might be impending on present persons in the context of intergenerational justice. Without such a clarification, it remains plausible that many authors are not disagreeing but rather talking past each other.

\section{What is the Standard of Intergenerational Justice?}

The second major debate on intergenerational justice revolves around the specific conception of justice in play, that is, around the nature of the standard that must be applied as well as around the identification of the contents of the duties that present generations supposedly have vis-à-vis past or future generations. Different conceptions of intergenerational justice conflict over how one should think about justice in the context of relations between non-necessarily-overlapping generations. This debate differs from conflicting understandings of the contours of justice, that is, conflicting understandings of which sorts of things are just and which are unjust. The debate on conceptions is prior to any kind of value judgement to particular cases.

In general, different conceptions of intergenerational justice share a normative frame of reference establishing a prohibition of depletion of those resources that are available to present generations, that is, the basket of capital and goods (not only 
physical, but also technological, institutional, environmental, cultural, relational) that can be used or passed on to subsequent generations. The choice between depletion and conservation acts as a borderline case of justice between non-overlapping generations. But that does not imply necessarily the equivalence between depletion and injustice, given that different standards may evaluate depletion differently. In less borderline circumstances, there might be instances in which savings are obligatory and instances in which present generations are required to invest for the benefit of succeeding generations. Different theories with different standards provide different moral outcomes.

A commutative standard establishes reciprocity: justice comes about in the equilibrium between that which is received and that which is transmitted, regardless of the size of the basket. With regard to non-necessarily-overlapping generations, direct reciprocity between present and past members is not possible, given that past generations cannot be active recipients. That does not entail necessarily the dissolution of duties grounded on reciprocity because, even though the creditor generation no longer exists in the present, the debtor generation does. Reciprocity can still be conceived of in terms of rights that are transmitted to descendants; but since the immediate heirs to such rights are members of the debtor generation, those same rights are transmitted to the subsequent descendants. Commutative standards in intergenerational relations hence express indirect reciprocity: each generation owes something to the succeeding generations because it received something from previous generations (Barry 1989; Shalit 1995; Wade-Benzoni 2002; McCormick 2009). There is thus a set of chain duties connecting non-contemporary generations. Not only are there duties to future generations, but those duties are justified in the light of a relationship with the past. In addition, the equal proportion between what has been received and what is rewarded suggests that present generations will have to leave to the next generations something at least equivalent to what they received from previous ones. This requires a prohibition of dissavings and of depletion. What is important is that the intertemporal balance is maintained between generations with regard to resources that can be passed on.

An aggregative standard, on the other hand, focuses on the size of the basket of available resources. Intergenerational justice comes about whenever a society's overall resources (such as welfare and capital) can be measured progressively throughout 
different times encompassing successive generations. Justice is determined from a principle aiming at the maximization of the size of the basket in one transgenerational community (Liedekerke and Lauwers 1997; Asheim and Buchholz 2007). The effects of actions undertaken (or of rules adopted) by members of present generations with the purpose of maximizing the available resources help to determine whether those actions are just or not.

An exclusively aggregative standard suggests that the most disadvantaged generations (those that are still at an early stage of the process of aggregate accumulation) will have to make the greatest sacrifices in order to accrue a basket of capital and goods which will be used by subsequent generations. This seems to equate justice with effectiveness. However, aggregative standards can be measured proportionately. For instance, equality (e.g. of opportunities, of power, of wealth, of happiness) might be a means of guaranteeing greater efficiency of well-being, in which case the general distribution is not only aggregative (total or average) but chiefly equitable of the greatest possible aggregation. Aggregative standards do not sentence necessarily the less advantaged generations to follow the prohibition of dissavings in a sacrificial manner. Rather, the aggregate of welfare and capital measured over various generations is never quantitatively closed since the community extends over time, and each new generation supposes the future existence of another generation that will integrate that same aggregate; the aggregate provisionally counted in the present includes fixed elements (the number of members of present and past generations) and possible elements (the indefinite estimate of members of future generations), and it is conceivable that there is a primacy of fixed elements to the detriment of possible elements when measuring the whole. An aggregative standard consists mostly in a principle of optimization that takes into account all members of a transgenerational community; since future members cannot be quantitatively determined in the aggregate, the prohibition of dissavings cannot be absolute as to undermine the maximization of the welfare and capital available to present generations.

Contrariwise, a distributive standard emphasizes the means by which available resources are apportioned to the different members of society. The standard follows a specific pattern in the distribution of capital and goods throughout time, even if the basket fails to be maximized and regardless of the use given to those resources in the 
past. There are different kinds of distributive theories of intergenerational justice since they adopt different standards.

A strict egalitarian stance qualifies as unjust any exercise of individual liberties that might leave future generations in unequal conditions of access to the available resources, even if future people are recognized as having rights to them. A less strict version of egalitarianism favours a priority view that benefits persons who are worse off even if that produces further social and economic inequalities between people living in the same or in different times. It is not equality as such that justifies positive discrimination in favour of those who are less privileged without it, but rather the need to include in morality a willingness to improve the conditions of the underprivileged.

Both kinds of standards are comparative. This poses problems concerning who and what is to be compared. With regard to whom, one possible answer is that present generations have the obligation to ensure that members of future generations are not left worse off than the remaining members of their (future) society; justice aims at diminishing (intragenerational) inequality in future societies (Sher 1979). Another possible answer involves comparing non-simultaneous generations: obligations that present generations might have to future generations require that future persons inherit welfare conditions that are not worse or less than those available to present persons (Barry 1999). With regard to what is compared, different answers (life expectancy? lifestyle? health? wealth? happiness?) bring about different theories of intergenerational justice: some compare the levels of welfare available to all members of a transgenerational society across different times (Honderich 1976; Layard 2005); others focus on the basic structural resources that support each generation's society (Rawls 1971); others emphasize fundamental individual capabilities to achieve outcomes in accordance with a valuable lifestyle (Sen 1999; Page 2007; Watene 2013); and others measure equality in the light of a scale encompassing both individual opportunities free from obstacles and minimum collective standards of welfare (Cohen 2011).

Non-comparative standards avoid such problems. They focus on a specific threshold beneath which no moral agent can fall, regardless of other agents' positions (Frankfurt 1987). Sufficientarian standards of this sort establish duties for the creation of conditions in which as many people as possible have enough resources to pursue the aims and aspirations they affirm. Like prioritarianism, sufficientarianism accepts 
unequal outcomes of the distribution of capital and goods as just; and it also expresses moral principles in favour of the underprivileged. However, unlike prioritarianism, it defines the threshold between privileged and underprivileged as free access to those resources that are sufficient in order to achieve a specific state of affairs (economically, politically, culturally, etc.); and it applies the priority view solely to those persons underneath such a threshold, independently of the time they live in (Crisp 2003; Benbaji 2005; Huseby 2010; Shields 2012). Those that stand above the threshold can claim no moral rights in intergenerational relations since justice aims solely at universalizing sufficiency. $^{7}$

There have been attempts to conceive of intergenerational justice in terms of mixed standards. Mostly, they regard intergenerational justice as an equilibrium between a specific kind of equality and individual liberty.

For communitarian views, individuals are born into pre-existing communities whose preservation over time makes them transgenerational in kind. Individuals have responsibilities in transgenerational communities if they share 'lifetime-transcending interests' (Thompson 2009), that is, interests that have as their subject matter events, objects, or states of affairs that pre-exist or transcend a member's lifetime. These special interests play an important role in the lives of individuals and in the formation of their identities; but, more importantly, their existence makes it likely that those who have them will be inclined to make demands on their successors. Responsibilities towards non-overlapping generations are part of the strategy for the preservation of the cultural identity of communities - they constitute a theory of intergenerational justice only if derived from this idea of 'transtemporal' group identity. In this sense, there are no generational privileges established by temporal conditions. Present generations are simply the actualization of community life, and the available resources belong to the community as a whole over time.

Libertarian perspectives are methodologically different. Their reference is no longer the individual in the community, but the individual before the community, with her own personal freedom including self-ownership and a moral power to appropriate

\footnotetext{
7 The most prominent defence of sufficientarianism in intergenerational relations goes back to the (normative) definition of 'sustainable development' present in Our Common Future (also known as the Brundtland Report), published in 1987 by the World Commission on Environment and Development, according to which development is sustainable if it does not compromise the ability of future generations to meet their own needs.
} 
unowned external resources. Within such framework, individual liberty requires some sort of 'transtemporal' protection achieved only by the enforcement of a proviso requiring 'at least where there is enough and as good left for others' (Locke 1988, §27). This implies a formulation of the following type: 'the continued legitimacy of private ownership from the standpoint of self-ownership depends on each successive generation obtaining the equivalent of a per capita share of unimproved, undegraded land' (Arneson 1991, 53); or "no individual may degrade or use up more than her per capita share of natural resources without sustainable offsetting compensation' (Steiner and Vallentyne 2009, 63). The libertarian approach focuses on knowing to what extent one's existence deprives someone else of something she could otherwise have benefited from; the Lockean proviso functions as a guardian of individual liberty across generations. Equality has a role to play in this strategy insofar as it refers to equal rights to resources and to an equal treatment of individuals with respect to their rights, never to an equal distribution of resources or property. The Lockean proviso is the standard for guaranteeing such equality - an equality of the formal conditions of access to resources not necessarily transformed. Ultimately, the restoration of the conditions of originality boils down to the question of each individual leaving a condition of freedom to be at least identical to that which would have existed had she not existed. It is, after all, a demand to equalize (in a formal sense) freedom understood as the absence of unjustified restrictions on the action of individuals.

John Rawls' liberal egalitarianism suggests a different setting. In the original position, in which every generation is represented, the veil of ignorance prevents contracting parties from knowing to which generation they will belong. This leads them to determine a 'just savings rate'. According to Rawls, intergenerational relations change according to different stages of social development. In an accumulation stage, present generations are bound by a savings principle to the extent that it is necessary to enable subsequent generations to stay above a minimum threshold of justice; the savings principle would include preserving the gains of culture and civilization, maintaining fair institutions and putting aside a suitable amount of investment in order to guarantee a sustainable and just basic structure over time (Rawls 1971, 254). In a later stage of stability, where fair institutions are sufficiently established, the savings principle is substituted by an obligation to leave to future generations at least the 
equivalent of what present generations received from the previous generation (Rawls 1971, 257).

The just savings principle in the accumulation stage is justified by the need to establish fair institutions that protect the basic freedoms of all individuals (e.g. physical integrity, freedom of expression, etc.). Even though the accumulation stage has the purpose of improving the social and economic conditions of the most disadvantaged individuals, the stability stage in a fairly structured society cannot be achieved by violating basic freedoms. Rather, individuals from different generations agree on the principles of justice ${ }^{8}$ ensuring that the members of each generation are integrated into a basic structure of society that protects their most fundamental rights.

\section{Empirical changes as theoretical challenges}

Theories of intergenerational justice lead to different normative conclusions even without addressing the specific characteristics of the basket that constitutes the substance of intergenerational responsibilities (e.g. retirement pensions, industrial waste, public debt interests, military technology, mass migrations, scarcity of environmental and food resources, unemployment rates, normative frameworks for problems of bioethics such as abortion, reproduction scenarios, legal wrongful life cases, etc.). However, the determination of rigid standards might be problematic in a necessarily transhistorical context. ${ }^{9}$

Firstly, there are several ways of understanding transhistoricity with regard to the legitimate usage of available resources. For instance, commutative theories reproduce the instruments of inheritance and restitution. Present generations inherit resources from their ancestors, and in turn are obliged to give back what they received, this time to the following generation which also inherits those resources. The relations between moral agents and the available resources resemble property relations, and the transmission of resources from one generation to the next mirrors a historical timeline.

\footnotetext{
${ }^{8}$ In A Theory of Justice, Rawls justifies the just savings principles by means of what he calls a 'motivational assumption' according to which individuals have a natural motive of care for their descendants (Rawls 1971, 128-9). In his later Political Liberalism, however, he shows reservations about the motivational assumption and instead claims that contractors simply agree to principles of savings that they want all previous generations to have followed (Rawls 1993, 273-4).

${ }^{9}$ For the thesis that there can be no transhistorical theory of justice and therefore no valid theory of intergenerational justice either, see Ball (1985).
} 
In the opposite sense, the popular saying (often presented as an ancient Indian proverb) 'We do not inherit the earth from our ancestors; we borrow it from our children' makes use of a different setting. It reproduces the instruments of loans rather than of inheritances and this entails, on the one hand, that the relations between present persons and the available resources does not resemble property relations but rather the mere possession of that which belongs to other persons; and, on the other hand, that the timeline referred to is psychological rather than historical since the loan mirrors the course of memory, backwards, from a generation of proprietors that never actually comes into existence because it is always in the future. A third kind of setting can be found in Hans Jonas' theory of moral responsibility, according to which ethics must become non-anthropocentric in order to ensure the survival of the planet and of all life therein (Jonas 1979). According to Jonas, time in intergenerational relations should be regarded as cosmic rather than simply historical or psychological, since only then will humans understand that their relation with the available resources resembles neither property nor loans but is instead a relation of identity. The imperative of responsibility involves caring for available resources as one cares for oneself, not merely in order to act justly towards succeeding generations but in order to ensure the survival of the human species. ${ }^{10}$ In the end, the fact that the relations between present generations and available resources are framed by different conceptions of time determines varied theoretical responses.

Secondly, the idea of succeeding generations is merely an abstraction (Barry 1977) since it assumes that one entire group of persons departs as another arrives on the scene, whereas population replacement is a continuous process. This makes it difficult to apply standards of intergenerational justice in accordance with the threefold division of generations. For nontransitive theories distinguishing between three generations, G1 (the past), G2 (the present), and G3 (the future), the line between them (the frontier between simultaneity and non-simultaneity) may not be easily drawn. For instance, is a foetus likely to be born tomorrow a member of G3 on equal terms with persons who will be born in 100 years? Or is she a rights-holder of G2 with a special status? Similarly, transitive theories distinguishing between G1 (the oldest cohort), G2 (the middle-one) and G3 (the youngest one), in which at least two of them overlap, faces suchlike problems: is a baby born today a member of G2 or G3? Or of both? Is she

\footnotetext{
${ }^{10}$ For an anthropocentric approach to environmental protection, see Woods (2016).
} 
mainly a duty-bearer or a right-holder in an intergenerational context? Hard cases occurring between the present and a near future seem to be likely candidates to fall under the purview either of a future-rights-of-future-persons approach, a present-rightsof-future-persons approach or a present-rights-of-present-persons approach to intergenerational justice.

Thirdly, specific empirical occurrences prompt different theoretical challenges. For instance, depending on the preferred standard, the fact that past generations may not have fulfilled the obligations that present persons recognize as binding on all generations can affect the extent and nature of intergenerational responsibilities. But the most prominent examples relate to demographic fluctuations. In this sense, population ethics forces itself into debates on intergenerational justice. Changes in the number of members of a community (including the possibility of human extinction as an effect of human action) can either provide reasons for altering or for preserving the contents of the intergenerational basket, depending on the theory adopted.

The best example of such theoretical disparity consists in what came to be known as the repugnant conclusion (Parfit 1987): Following a simple aggregative standard, for any possible population in which members have a high quality of life, there must be some much larger imaginable population whose existence would be better even though its members have lives that are barely worth living. Scepticism about the possibility of a satisfactory population ethics might lead one to embrace this line of reasoning (Tännsjö 2002). Most authors, though, tend to believe that such an endeavour is counterintuitive, and they often circumvent the repugnant conclusion by rejecting aggregative standards in favour of a preferred pattern of distribution of capital and welfare. But aggregative standards can still be preserved if additional criteria for measuring and counting welfare are taken into account. The principle of optimization might balance some kind of proportionality with aggregation in such a way that the measured value varies with the number of already existing lives - for instance, by increasing value when the number of lives is smaller (Hurka 1983; Ng 1989; Sider 1991).

One of the things that can be inferred from debates on the repugnant conclusion is that standards of intergenerational justice are unlikely to be applied to same-numberof-people choices. This has important consequences to contents such as prohibitions of 
dissavings, given that leaving equal resources to succeeding generations which can be twice as numerous actually entails increasing the number of available resources. In addition, it involves widening the scope of intergenerational justice beyond the mere exercise of thought experiments about the future since actual empirical data need to be taken into account when setting the right standards.

The difficulties inherent in such a task are not only ethical but also political. Democratic policies and law-making are actually more concerned with present addressees and short-term (often electoral) effects than with the long term, and yet most proposals about intergenerational justice seem to rely on democratic instruments of implementation (Kates 2015), such as representation (of future generations), for instance (Beyleveld et al. 2015). The theoretical challenge is therefore also disciplinary. Whereas same-number-of-people choices can be tackled by ideal theories, it seems that different-number-of-people choices leave room for non-ideal types of reasoning.

\section{Conclusion}

Certain institutions and practical proposals aimed at defending the interests and rights of non-present generations are already in play, and this includes the increasing tendency to upgrade such rights to the status of constitutional rights or even to consider them part of international human rights law (Riley 2016). In addition, the temporal distance between some generations increases uncertainty as to the effects of present actions or to the nature of future generations' available resources; the temporal direction of causation may generate problems of asymmetry of power across time; the lack of temporal coexistence with remote generations is insufficient to remove the interests that present persons may have in the interests of future persons. All this is constitutive of a problematic to which there should be at least a tentative reply.

Ultimately, taking the basilar models of the most notorious theories of intergenerational justice seriously can be decisive in dealing with problems specific to contemporary societies. But the debate is still far from demonstrating that today's societies must embrace a particular theory of intergenerational justice without which they cannot be moral (and survive). It will be up to a responsible exercise of citizenship to ensure that these arguments are not reduced to inconsequential thought experiments. 


\section{Works Cited}

Adams, Robert Merrihew. 'Existence, Self-Interest, and the Problem of Evil.' Nous 13 (1979): 53-65.

Arneson, Richard. 'Lockean Self-Ownership: Towards a Demolition.' Political Studies 39 (1991): 36-54.

Asheim, Geir B., and Wolfgang Buchholz. 'The Malleability of Undiscounted Utilitarianism as a Criterion of Intergenerational Justice.' Justifying, Characterizing and Indicating Sustainability. Ed. Geir B. Asheim. Dordrecht: Springer, 2007. 63-82.

Baier, Annette. 'The Rights of Past and Future Persons.' Responsibilities to Future Generations: Environmental Ethics. Ed. Ernest Partridge. New York: Prometheus Books, 1981. 171-183.

Ball, Terence. 'The Incoherence of Intergenerational Justice.' Inquiry 28 (1985): 321337.

Barry, Brian. 'Justice Between Generations.' Law Morality \& Society: Essays in Honor of H.L.A. Hart. Eds. P.M.S. Hacker and Joseph Raz. Oxford: Clarendon Press, 1977.

----- Liberty and Justice. Oxford: Clarendon Press, 1989.

----- 'Sustainability and Intergenerational Justice'. Fairness and Futurity. Ed. Andrew Dobson. Oxford: Oxford UP, 1999. 93-117.

Beckerman, Wilfred, and Joanna Pasek. Justice, Posterity, and the Environment. Oxford: Oxford UP, 2001.

Benatar, David. Better Never to Have Been: The Harm of Coming into Existence. Oxford: Clarendon Press, 2006.

Benbaji, Yitzhak. 'The Doctrine of Sufficiency: A Defence.' Utilitas 17 (2005): 311332.

Beyleveld, Deryck, Marcus Düwell and Andreas Spahn. 'Why and How Should We Represent Future Generations in Policymaking?' Jurisprudence 6 (2015): 549-566. 
Campos AS. Intergenerational Justice Today. Philosophy Compass. 2018;e12477.

https://doi.org/10.1111/phc3.12477

Boonin, David. The Non-Identity Problem \& the Ethics of Future People. Oxford: Oxford UP, 2014.

Brännmark, Johan. 'Future Generations as Rightholders.' CRISPP 19 (2016): 680-698.

Brock, Dan W. 'The Non-Identity Problem and Genetic Harms: The Case of Wrongful Handicaps.' Bioethics 9 (1995): 269-275.

Buchanan, Allen, Dan W. Brock, Norman Daniels and Daniel Wikler. From Chance to Choice: Genetics and Justice. Cambridge: Cambridge UP, 2000.

Burke, Edmund. Reflections on the Revolution in France. Ed. Russell Kirk. Chicago: Gateway, 1962.

Cohen, G.A. On the Currency of Egalitarian Justice, and Other Essays in Political Philosophy. Ed. Michael Otsuka. Princeton: Princeton UP, 2011.

Crisp, Roger. 'Equality, Priority, and Compassion.' Ethics 113 (2003): 745-763.

De George, Richard. 'The Environment, Rights, and Future Generations.' Responsibilities to Future Generations: Environmental Ethics. Ed. Ernest Partridge. New York: Prometheus Books, 1981. 157-166.

Delattre, Edwin. 'Rights, Responsibilities and Future Persons.' Ethics 82 (1972): 254258.

Elliot, Robert. 'The Rights of Future Persons.' Journal of Applied Philosophy 6 (1989): 159-169.

Feinberg, Joel. 'The Rights of Animals and Unborn Generations.' Philosophy and Environmental Crisis. Ed. William T. Blackstone. Athens: University of Georgia Press, 1974. 43-68.

Fieser, James. 'The Correlativity of Duties and Rights.' International Journal of Applied Philosophy 7 (1992): 1-8.

Frankfurt, Harry. 'Equality as a Moral Ideal.' Ethics 98 (1987): 21-43.

Gewirth, Alan. Reason and Morality. Chicago: University of Chicago Press, 1978. 
Campos AS. Intergenerational Justice Today. Philosophy Compass. 2018;e12477.

https://doi.org/10.1111/phc3.12477

Gheaus, Anca. 'The Right to Parent and Duties Concerning Future Generations.' The Journal of Political Philosophy 24 (2016): 487-508.

Gosseries, Axel. 'Historical Emissions and Free-Riding.' Ethical Perspectives 11(1) (2004): 36-60.

----- 'On Future Generations' Future Rights.' The Journal of Political Philosophy 16 (2008): 446-474.

Griffith, Aaron M. 'The Rights of Future Persons and the Ontology of Time.' Journal of Social Philosophy 48 (2017): 58-70.

Hanser, Matthew. 'Harming Future People.' Philosophy \& Public Affairs 19 (1990): 4770.

Harman, Elizabeth. 'Harming as Causing Harm.' Harming Future Persons: Ethics, Genetics and the Nonidentity Problem. Ed. Melinda A. Roberts and David T. Wasserman. New York: Springer, 2009. 137-154.

Herstein, Ori J. 'The Identity and (Legal) Rights of Future Generations.' The George Washington Law Review 777 (2009): 1173-1215.

Heyd, David. Genethics. Moral Issues in the Creation of People. Berkeley: University of California Press, 1992.

Honderich, Ted. Three Essays on Political Violence. Oxford: Blackwell, 1976.

Hurka, Thomas. 'Value and Population Size.' Ethics 93 (1983): 496-507.

Huseby, Robert. 'Sufficiency: Restated and Defended.' The Journal of Political Philosophy 18 (2010): 178-197.

Jefferson, Thomas. Jefferson. Political Writings. Eds. Joyce Appleby and Terence Ball. Cambridge: Cambridge UP, 2004.

Jonas, Hans. Das Prinzip Verantwortung. Frankfurt: Insel, 1979.

Kates, Michael. 'Justice, Democracy, and Future Generations.' CRISPP 18 (2015): 508528. 
Campos AS. Intergenerational Justice Today. Philosophy Compass. 2018;e12477.

https://doi.org/10.1111/phc3.12477

Kavka, Gregory. 'The Paradox of Future Individuals.' Philosophy and Public Affairs 11 (1981): 93-112.

Kramer, Matthew H. 'Getting Rights Right'. Rights, Wrongs and Responsibilities. Basingstoke: Palgrave, 2001. 28-95.

Kumar, Rahul. 'Who Can Be Wronged?' Philosophy and Public Affairs 31 (2003): 99118.

Layard, Richard. Happiness. Lessons from a New Science. London: Allen Alan, 2005.

Liedekerke, L. van, L. Lauwers. 'Sacrificing the Patrol: Utilitarianism, Future Generations and Infinity.' Economics and Philosophy 13 (1997): 159-174.

Locke, John. Two Treatises of Government. Ed. Peter Laslett. Cambridge: Cambridge UP, 1988.

Macklin, Ruth. 'Can Future Generations Correctly Be Said to Have Rights?' Responsibilities to Future Generations: Environmental Ethics. Ed. Ernest Partridge. New York: Prometheus Books, 1981. 151-156.

Mazor, Joseph. 'Liberal Justice, Future People, and Natural Resource Conservation.' Philosophy \& Public Affairs 38 (2010): 380-408.

McCormick, Hugh. 'Intergenerational Justice and the Non-Reciprocity Problem.' Political Studies 57 (2009): 451-458.

McMahan, Jeff. 'Wrongful Life: Paradoxes in the Morality of Causing People to Exist.' Bioethics. Ed. John Harris. Oxford: Oxford UP, 2001. 445-475.

Ng, Yew-Kwang. 'What Should We Do About Future Generations? Impossibility of Parfit's Theory X.' Economics and Philosophy 5 (1989): 135-253.

Page, Edward A. 'Intergenerational Justice of What: Welfare, Resources or Capabilities?' Environmental Politics 16 (2007): 453-469.

Parfit, Derek. Reasons and Persons. Oxford: Clarendon Press, 1987.

----- 'Future People, the Non-Identity Problem, and Person-Affecting Principles.' Philosophy \& Public Affairs 45 (2017): 118-157. 
Campos AS. Intergenerational Justice Today. Philosophy Compass. 2018;e12477.

https://doi.org/10.1111/phc3.12477

Pletcher, Galen K. 'The Rights of Future Generations.' Responsibilities to Future Generations: Environmental Ethics. Ed. Ernest Partridge. New York: Prometheus Books, 1981. 167-170.

Rawls, John. A Theory of Justice. Cambridge, MA: Harvard UP, 1971.

----- Political Liberalism. New York: Columbia UP, 1993.

Riley, Stephen. 'Architectures of Intergenerational Justice: Human Dignity, International Law, and Duties to Future Generations.' Journal of Human Rights 15 (2016): 272-290.

Rivera-López, Eduardo. 'Individual Procreative Responsibility and the Non-Identity Problem.’ Pacific Philosophical Quarterly 90 (2009): 336-363.

Routley, Richard, and Val Routley. 'Nuclear energy and obligations to the future.' Inquiry 21 (1977): 133-179.

Schlossberger, Eugene. A Holistic Approach to Rights. Lanham: UP of America, 2008.

Schuessler, Rudolf. 'Non-Identity: Solving the Waiver Problem for Future People's Rights.' Law and Philosophy 35 (2016): 87-105.

Schwartz, Thomas. 'Obligations to Posterity.' Obligations to Future Generations. Ed. R. I. Sikora, Brian Barry. Philadelphia: Temple UP, 1978. 3-14.

Sen, Amartya. Development as Freedom. Oxford: Oxford UP, 1999.

Shalit, Avner de. Why Posterity Matters: Environmental Policies and Future Generations. New York: Routledge, 1995.

Sher, George. 'Compensation and Transworld Personal Identity.' Monist 62 (1979): 378-391.

Shields, Liam. 'The Prospects for Sufficientarianism.' Utilitas 24 (2012): 101-117.

Shiffrin, Sheana. 'Wrongful Life, Procreative Responsibility, and the Significance of Harm.' Legal Theory 5 (1999): 117-148.

Sider, Ted R.. 'Might Theory X be a Theory of Diminishing Marginal Value?' Analysis 51 (1991): 265-271. 
Campos AS. Intergenerational Justice Today. Philosophy Compass. 2018;e12477.

https://doi.org/10.1111/phc3.12477

Smolkin, Doran. 'Toward a Rights-Based Solution to the Non-Identity Problem.' Journal of Social Philosophy 30 (1999): 194-208.

Steiner, Hillel, and Peter Vallentyne. 'Libertarian Theories of Intergenerational Justice.' Intergenerational Justice. Ed. Axel Gosseries, Lukas H. Meyer. Oxford: Oxford UP, 2009. 50-76.

Sterba, James. 'Abortion, Distant Peoples, and Future Generations.' Journal of Philosophy 77 (1980): 424-440.

Tännsjö, Torbjörn. 'Why We Ought to Accept the Repugnant Conclusion.' Utilitas 14 (2002): 339-359.

Thompson, Janna. Intergenerational Justice. Rights and Responsibilities in an Intergenerational Polity. New York: Routledge, 2009.

Tremmel, Joerg Chet. A Theory of Intergenerational Justice. London: Earthscan, 2009.

Unruh, Charlotte. 'Present Rights for Future Generations.' Kriterion 30 (2016): 77-92.

Vanderheiden, Steve. 'Conservation, Foresight, and the Future Generations Problem.' Inquiry 49 (2006): 337-352.

Wade-Benzoni, Kimberly A. 'A Golden Rule Over Time: Reciprocity in Intergenerational Allocation Decisions.' The Academy of Management Journal 45 (2002): 1011-1028.

Wasserman, David. 'The Nonidentity Problem, Disability, and the Role Morality of Prospective Parents.' Ethics 116 (2005): 132-152.

Watene, Krushil. 'Nussbaum's Capability Approach and Future Generations.' Journal of Human Development and Capabilities 14 (2013): 21-39.

Weiss, Edith Brown. 'Our Rights and Obligations to Future Generations for the Environment.' The American Journal of International Law 84 (1990): 198-207.

Woods, Kerri. 'The Rights of (Future) Humans qua Humans.' Journal of Human Rights 15 (2016): 291-306.

Woodward, James. 'The Non-Identity Problem.' Ethics 96 (1986): 804-831. 
Campos AS. Intergenerational Justice Today. Philosophy Compass. 2018;e12477.

https://doi.org/10.1111/phc3.12477

Wrigley, Anthony. 'Harm to Future Persons: Non-Identity Problems and Counterpart

Solutions.' Ethical Theory and Moral Practice 15 (2012): 175-190.

Andre Santos Campos is Assistant Professor at the Nova University of Lisbon. His research interests are in the early modern period, in political theory, and contemporary jurisprudence. He is the author of Jus sive Potentia (CFUL, 2010), of Spinoza's Revolutions in Natural Law (Palgrave, 2012), and the editor of Spinoza: Basic Concepts (Imprint Academic, 2016), Spinoza and Law (Ashgate, 2014), and of Challenges to Democratic Participation (Lexington Books, 2014). 